\title{
BUREAUCRATIC ARRANGEMENT IN THE GOVERNMENT ADMINISTRATION PROCESS TOWARDS THE CONCEPT OF PUBLIC SERVICE BASED ON GOOD GOVERNANCE
}

\author{
Arifuddin N \\ STISIP Petta Baringeng Soppeng \\ Jl. Poros Salaonro, Kel. Ujung, Kec. Lilirilau Kab. Soppeng 90871 \\ Email :arifuddin2571@gmail.com
}

Submitted : 14/07/2021 Reviewed: 04/08/2021 Accepted:27/08/2021

\begin{abstract}
The bureaucracy arrangement in the government administration process studied in this research is how the role of the bureaucracy in the government administration process and the factors that influence the bureaucracy in the government administration process. This research is an empirical juridical legal research, by looking directly at the legal behavior of bureaucratic officials. Legal materials obtained regarding the structuring of government administration processes in Maros Regency are analyzed to find solutions to the problems faced. The results showed that the bureaucratic arrangement in the government administration process in Maros Regency, can be seen from the administrative management process by looking at the level of ease of service procedures, speed in service, low costs charged to the people, professionalism of officials in providing services. That the Maros Regency government in realizing the governance administration process has been running even though it is still not optimal. This is because there are still irregularities that occur in terms of public services to the community, although this is still in the stage of reforming towards excellent service standards. The influencing factor in the implementation of the bureaucracy in the implementation of public services in Maros Regency in serving the community is the availability of sufficient budget to support the operational implementation of public services. And the inhibiting factor is the service procedure factor, in addition to the lack of facilities and infrastructure.
\end{abstract}

Keywords : Government Administration Bureaucracy Arrangement; Maros Regency Regional Governance Law

DOI: $10.32801 /$ lamlaj.v6i2.271

\section{INTRODUCTION}

Bureaucracy is a public organization and has a public perspective and has been be- lieved to be a public service organ. Public services have broad implications in people's lives and development. Therefore, it is neces- 
sary to change the mindset of the bureaucratic apparatus to serve the community by treating people like entrepreneurs in serving their customers.

In people's lives, improving government apparatus resources in carrying out services to the community will increase public enthusiasm and trust in government which will ultimately increase community participation in development. And this can be done because the bureaucratic apparatus who carry it out are people who are chosen because they have the ability and expertise in their respective fields and are carried out in a structured manner by each separate section. ${ }^{1}$

Bureaucracy is the functions of government in a public context. Meanwhile, the duties of good governance are carried out entirely by the government which is a heavy task to provide services to the general public. ${ }^{2}$ However, even though it is difficult to carry out, but the bureaucratic arrangement must still be carried out considering the magnitude of the challenges faced by this nation and state in the future. In addition to regime change, changes in the world of bureaucracy have also undergone changes with the implementation of Regional Autonomy as a manifestation of the principle of decentralization.

In other words, that bureaucracy is a term that refers to modern organizations, both government and private ${ }^{3}$. However, in practice in everyday life, the term bureaucracy is only used in government organizations. Because the bureaucracy is run by government

\footnotetext{
1 M. Mas'ud Said, Birokrasi Di Negara Birokratis (Malang: Universitas Muhammadiyah Malang Press, 2007), 2

2 Ibid, 9

3 Ralph P. Hummel, The Bureaucratic Experince (New York: St. Martin Press, 1982), 19.
}

employees who are structured based on hierarchies and levels of office and have professional career backgrounds. ${ }^{4}$

To understand bureaucratic organizational culture, it is necessary to understand the strengths and weaknesses and the relationship between bureaucratic behavior, especially with parties outside the organization. One of the important tasks of the executive of the public bureaucracy is to maintain the organization. In the bureaucracy, the procedure for maintaining the organization can be done by maintaining economic resources and human resources and political support. ${ }^{5}$ So, it is better if a good public service organization must have human resources in accordance with the needs of the organization that is adjusted to the work volume of the organization. ${ }^{6}$

The bureaucracy in Indonesia during the New Order had poor report cards before the Reformation period. The problems that made report cards bad in the New Order era were related to the performance of the bureaucracy, especially in public services. Causing inefficient service functions, even causing waste in terms of budget. It is in the study of Public Administration Science referred to as "Pathology (disease) Bureaucracy". ${ }^{7}$

\footnotetext{
${ }^{4}$ Moerdiono, Birokrasi Dan Administrasi Pembangunan : Beberapa Pemikiran Pemecahan (Jakarta: Pustaka Sinar Harapan, 1992), 94

5 Achmad Nurmandi, "Perilaku Birokrasi Publik Di Indonesia : Sebuah Kajian Teoritis," Sosiohumaniora: Journal of Social Sciences and Humanities 7, no. 2 (2005): 155, https://jurnal.unpad.ac.id/ sosiohumaniora/article/view/5546.

6 Yusriadi Yusriadi and Misnawati, "Reformasi Birokrasi Dalam Pelayanan Publik (Studi Pelayanan Terpadu Satu Pintu)," Jurnal Ilmiah Ilmu Administrasi Publik 7, no. 2 (2017): 102, https://ojs.unm.ac.id/iap/ article/view/4954.

7 Mohammad Thahir Haning, "Reformasi Birokrasi Di Indonesia: Tinjauan Dari Perspektif Administrasi
} 
On the other hand, a bureaucratic organization that is able to provide public services effectively and efficiently to the community if its structure is more decentralized. Because, due to the decentralization of the existing structure, it is easier to realize the interests of the community, so that the bureaucratic apparatus can quickly serve the community as expected by the customer community. ${ }^{8}$

As a result of poor bureaucratic services to the community, the public's trust in the public bureaucracy is getting lower. Data from the survey results of the International Transparency Institute in 2017 where Indonesia ranks 129 out of 188 countries surveyed in terms of Bureaucratic Pathology. The implication is that the performance of the bureaucracy has not given satisfaction (satisfaction). According to the survey, it is categorized as severe because it has affected all levels of government. ${ }^{9}$ In fact, the behavior of bureaucrats who tend to commit corruption, collusion, and nepotism increasingly causes a negative image of the bureaucracy in society which can affect the economic growth of a country. ${ }^{10}$

The Reformation Order by promoting democratization has changed the order of democratic life, but this does not apply to

Publik," JAKPP (Jurnal Analisis Kebijakan \& Pelayanan Publik) 4, no. 1 (2018): 31-32, https:// journal.unhas.ac.id/index.php/jakpp/article/ view/5902.

8 Yusrialis, "Budaya Birokrasi Pemerintahan (Keprihatinan Dan Harapan)," Sosial Budaya 9, no. 1 (2012): 102, http://ejournal.uin-suska.ac.id/index. php/SosialBudaya/article/view/372.

9 Haning, "Reformasi Birokrasi Di Indonesia: Tinjauan Dari Perspektif Administrasi Publik.",32

${ }^{10}$ Imran Rasul and Daniel Rogger, "Management of Bureaucrats and Public Service Delivery: Evidence from the Nigerian Civil Service," The Economic Journal 128, no. 608 (February 1, 2018): 413-446, https://doi.org/10.1111/ecoj.12418. the existence of a "bureaucracy" within the government. Entering the Reform Order, reforms were carried out in all fields, including reforms in the field of government by maximizing the potential possessed by a region, by changing the centralized government system to a decentralized system by realizing good governance. ${ }^{11}$

In its development, democracy has experienced global environmental influences. Indonesia as a developing country has succeeded in becoming a relatively strong democracy. This is evident in the reform era, democracy in Indonesia has developed progressively, marked by the shift of representative democracy to participatory democracy, the direct elections in determining leaders at the national and local levels. This important shift was confirmed through direct presidential elections (pilpres). We should be proud that in 2019 the presidential election was held in smooth conditions, so that Indonesia became the most democratic country in Asia, because it was carried out peacefully and without violence.

Law No. 22 of 1999 concerning Regional Government is a milestone in the change in governance, which was later replaced by Law no. 32 of 2004 concerning Regional Government, and then what is currently in effect is Law no. 23 of 2014 concerning Regional Government. Various kinds of local government implementing regulations, become a new chapter in the administration of regency/ municipal government in Indonesia. These changes, of course, have significant consequences, especially how the role of the bureaucracy in carrying out its duties and functions. For example, the authority of the central government is delegated, except for main

\footnotetext{
${ }^{11}$ Haning, "Reformasi Birokrasi Di Indonesia: Tinjauan Dari Perspektif Administrasi Publik."
} 
affairs. This has also caused service functions to be decentralized from the central government to local governments.

The district government that is used as the object of research is the Maros Regency Government, considering that Maros Regency is one of the areas directly adjacent to Makassar City as the Capital of South Sulawesi Province which can be used as comparison material in the implementation of public services to the community.

Maros Regency has an area of 1,619.12 $\mathrm{km}^{2}$ and is located at an altitude of $881 \mathrm{~m}$. This area, Maros district, is divided into 14 sub-districts, which are spread out into 103 villages / sub-districts. from the 103 villages/ sub-districts in Maros district, 10 villages are located in coastal areas, 5 villages are in valley areas, 28 villages are in hilly areas, and the remaining 60 villages/villages are in plains/ sloping areas. The capital city of Maros district is $\pm 30 \mathrm{~km}$ from Makassar City which is the capital of South Sulawesi province.

As an effort to improve the quality of government administration that refers to the general principles of good governance and based on the provisions of laws and regulations, and to resolve problems in the administration of government, as well as a legal basis for Government Agencies and/or Officials, community members, and other parties. -other parties related to Government Administration in an effort to improve the quality of government administration ${ }^{12}$, Law no. 30 of 2014 concerning Government Administration.

The research entitled "Bureaucracy Arrangements in the Government Administra-

\footnotetext{
${ }^{12}$ See Article 2 jo Article 3 Law no 30 of 2014 Concerning, Government Administration, which explains the Purpose and Objectives of the establishment of Law no. 30 of 2014.
}

tion Process Towards Public Services Based on Good Governance" is expected to be a solution to problems related to the government administration process, especially in the Maros Regency Government.

In this study, the authors focus on the discussion of how the role of the bureaucracy in realizing the principles of public administration which include timeliness, speed, convenience and affordability ${ }^{13}$ so as to realize the function of good public services which is one of the characteristics of good governance, which is the process of government administration, especially in the scope of the district government, so that changes in bureaucratic culture towards a better public service system can be developed for the creation of excellent service.

From the various explanations that have been described above, the authors limit the problems to be studied as follows: How is the arrangement of the bureaucracy in the process of government administration in Maros Regency and What are the factors that influence the structuring of the bureaucracy in the process of government administration in Maros Regency?

\section{METHOD}

Based on the problem that has been formulated that focuses on Bureaucratic Arrangement in the Government Administration Process in Maros Regency, this research

\footnotetext{
${ }^{13}$ Article 4 of Law No 25 of 2009, Concerning Public Service Law, which states that the Implementation of Public Services is based on; a) Public interest, b) rule of law, c) Equality of rights, d) Balance of rights and obligations, e) Professionalism, f) Participatory, g) Equality of treatment / non-discrimination, h) Openness, i) accountability, j) facilities and special treatment for vulnerable groups, k) Timeliness, and m) Speed, convenience, and affordability
} 
is included in the category of sociological or juridical empirical legal research, which includes research on legal identification and legal effectiveness in society. ${ }^{14}$

In accordance with the type of research used, to see the effectiveness of law in society, laws and regulations related to bureaucratic arrangement in the government administration process in the Maros Regency Government Scope are used, as well as conducting research in the field to see the legal behavior of bureaucratic apparatus in providing services to Public. ${ }^{15}$

Legal materials obtained both through literature and field research are studied in depth so that they can answer and provide solutions to bureaucratic problems in the Maros Regency Government Scope, so as to create excellent service that can satisfy the community.

\section{ANALYSIS AND DISCUSSION}

Bureaucratic Arrangements in the Government Administration Process in Maros

\section{Regency}

The practice of providing services to the public in the public service sector is still in the spotlight. Service is the most important thing in an organization that is engaged in services, especially if the organization is a noncommercial organization which is usually the government. Thus, the community is in dire need of the best service to the needs of the community.

Reflecting on the poor service of the bureaucracy in the past which led to a lack of public trust in the performance of a neutral

\footnotetext{
${ }^{14}$ Mukti Fajar Nur Dewata and Yulianto Achmad, Dualisme Penelitian Hukum Normatif \& Empiris (Yogyakarta: Pustaka Pelajar, 2015),153

${ }^{15}$ Soerjono Soekanto, Pengantar Penelitian Hukum (Jakarta: UI Press, 1983), 51
}

bureaucracy, bureaucratic arrangement is not easy in practice. The administration does not go through a smooth road, but there are certain obstacles that must be passed in order to restore and achieve an image of excellent service.

Various policies taken to create a neutral bureaucracy in the administration of government in Maros Regency have been pursued. Bureaucratic arrangement is carried out by applying public service ethics as mandated by Law no. 25 of 2009 concerning Public Services. ${ }^{16}$, which is manifested by openness, active participation and community empowerment. The government administration arrangement in Maros Regency is continuously being improved in terms of service. As stated by the resource person that:

"The Maros Regency Government in carrying out public services continues to strive to make improvements in terms of service to the community which is always oriented to the principles of Good Governance in order to create excellent service". ${ }^{17}$

The government apparatus in Maros Regency has a role in carrying out services both to government and private organizations. This shows that the success of government implementation is determined by the extent to which the role of the bureaucracy in providing services to the community. Considering that in the present and future eras, it is very necessary for bureaucrats who are able to manage government management to be carried out successfully, where the process is certainly related to efforts to organize and see if the service of the apparatus really satisfies

\footnotetext{
${ }^{16}$ Law Number 25 of 2009 concerning, Public service law.

${ }^{17}$ Assistant I Governance law Administration of Maros Regency, Interview by Arifuddin N, (14 Januari 2020)
} 
the community.

The policy taken by the Regional Government of Maros Regency regarding public services in its implementation is an instrument of government policy for the welfare of the community in the regional development process.

The quality of service can be seen in the elements of the effectiveness and efficiency of services carried out by the Maros Regency government apparatus. The effectiveness and efficiency of services can be measured in terms of ease, speed, low costs charged to the community and work professionalism.

The public service that is used as the object of this research only tries to see how far the role of the government is in optimizing public services regarding the provision/making of population documents and civil records for the people in Maros Regency, in relation to supporting the administrative process of government by the bureaucratic apparatus of the Maros Regency Government.

\section{The Issuance of Identity Cards}

The bureaucratic arrangement of the government administration process in Maros Regency which is used as one of the samples to be studied is to see the role of the function of the bureaucracy in terms of public services, especially how the service of making Identity Cards (KTP) of Maros Regency.

Identity card (KTP) as the legitimacy of every resident including residents who live in the Maros Regency area. The identity card is used by residents and as a citizen's identity as well as providing citizenship status.

For the service of KTP (identity card) in Maros Regency, currently it is still centralized in the Department of Population and Civil Registry of Maros Regency. Unlike the case in Makassar City, where the ID card service is carried out in each subdistrict office, in the context of excellent service in line with regional financial capabilities, each sub-district will be placed/ installed with computer tools/equipment for inputting ID cards.

Along with the increasing capacity of the Maros Regency Government, it will implement a service system and make ID cards in each sub-district within the Maros Regency. However, the basic consideration in implementing the KTP service program in the sub-districts is the availability of an adequate budget to provide supporting facilities and infrastructure.

The results of the field research show that the computer facilities used by the Maros Regency Government apparatus in serving the making of ID cards are only available 4 units of computers, where one computer serves 4 sub-districts within the Maros Regency.

The management fee specified in the rules for issuing identity cards is free of charge, but based on the statement of the Maros Regency bureaucratic apparatus as stated in the interview above, that there are people who understand the additional costs that are not imposed by the ID card maker reveals that;

"And for fees, there are usually people/ applicants who voluntarily give additional fees to ID card service officers, not to bribe them to be served quickly, but it is only based on the understanding of them." 18

Regarding the additional cost, one of

\footnotetext{
${ }^{18}$ Department of Population and Civil Registration, Maros Regency, Interview, by Arifuddin.N (16 Januari 2020) .
} 
the informants who was taking care of the ID card revealed that:

"When applying for an ID card, we usually give just a little tip so that the business and the required identity card can be completed quickly". ${ }^{19}$

The responses from resource persons who were met at the time of applying for an ID card, stated that the delay in processing was due to the fact that in applying for ID card services they often encountered several obstacles that caused delays in the implementation of the services they proposed. These obstacles include technical and non-technical barriers.

The technical obstacles are usually due to a lack of requirements as a completeness file submitted by the community so that it must be postponed and re-checked at the village office. Meanwhile, non-technical obstacles are usually caused by the officer in charge of dealing with this transaction being absent, due to a sudden assignment from the district that must be completed immediately, so that the files submitted by the people have to be postponed to be completed.

The Obstacles in Public Services in Maros Regency

The implementation of its functions to serve the people, demands to carry out satisfactory services and excellent service that is coveted by the community so that the optimization of the performance of the Maros Regency Government bureaucracy can run well. To answer this challenge, the Regional Government of Maros Regency is still faced with several problems.

This is clearly illustrated in the Iden-

\footnotetext{
${ }^{19}$ Interview with resource person, (16 Januari 2020).
}

tity Card service, where the apparatus/ officers for making identity cards at the Population Service only rely on 6 (six) computers to serve the community in 14 sub-districts (divided into 103 Villages/ Kelurahan) within the Maros Regency. This get worsened by the condition of the broken computers. In addition to computers, the Maros Regency bureaucracy has 4 printing tools for all sub-districts in Maros Regency. Even though from the results of the author's monitoring there have been additional computers and printing machines for testing the implementation of making ID cards in the subdistrict, this has not been realized.

From the results of the study, a the source person said that;

"Department of Population officers in carrying out public service tasks are already maximal, but to improve the quality of their work and capacity they still need training on how to provide good service to the community." 20

\section{Effectiveness of Public Services in Ma- ros Regency}

To determine the effectiveness of an organization in carrying out public services, it is by looking at the results or objectives that can be described from the Maros Regency Government bureaucracy:

a. The Timeliness of Service quality of service can be optimal if it requires as a consumer or the public to get service not to wait too long. Based on the results of the study that the timeliness of public services, es-

\footnotetext{
${ }^{20}$ Administrative Section of the Population and Civil Registry Office of Maros Regency, Interview by, Arifuddin.N (20 Januari 2020).
} 
pecially in the service of making ID cards in Maros Regency, was considered good. Technical obstacles are usually due to a lack of requirements as a complete file submitted by the applicant, in addition to technical facilities such as damage to computers and printing equipment or lack of paper for printing such as ID cards. Meanwhile, non-technical obstacles making the service times delayed are usually caused by officials who have authority over public services that are not in place, for reasons of getting other assignments or having personal needs so that they cannot carry out their duties. However, this problem in the ID card service is usually the officer who is unable to be replaced by another officer. The punctuality of completion and the clarity of the service time schedule also need to be considered by the officers or service providers so as not to cause confusion in the community regarding the identity card service in Maros Regency. The problem of clarity of service time schedule is one element of a series of elements that can affect service quality. However, the results of interviews with informants revealed that:

"The length of time for making ID cards is usually 1-7 days, the length of time for completing an ID card is due to technical problems such as a power failure or a computer that is damaged, the lack of applicants because it takes 9 applicants to print ID cards so that at the time of printing it doesn't waste time. -and paper". ${ }^{21}$

The speed of completion of the Identity Card, it can be concluded that the tendency of the community or customers to request fast service has been attempted by the service providers/officers so that the effectiveness of the service can be implemented properly. Here it can be seen that in public services regarding punctuality can be categorized as having supported a process of democratization of government in Maros Regency.

b. Compliance with Rules

To determine the level of effectiveness of a government administration process, which is by making sure in every implementation of the public service process in accordance with applicable procedures. This is intended to optimize the role and function of every public institution/organization within the Maros Regency Government, which in turn becomes an area that has excellent public service quality. Specifically regarding the making of ID cards in Maros Regency, there are indications that there is an ID card making service that should be carried out starting at the RT/RW, village/kelurahan, subdistrict level and then to the Population and Civil Registry Office of Maros Regency. However, what happens is that many people as applicants go directly to the Population and Civil Registry Office of Maros Regency by filling out a form that is known and signed by the Village

${ }^{21}$ Interview with resource person, (22 Januari 2020) 
Head where the applicant is domiciled. However, based on the results of interviews as revealed above, the bureaucratic apparatus of the KTP service at the Maros Regency Population and Civil Registry Office has carried out a service procedure that is in accordance with the rules, in the sense that the organization where they work has carried out public services to the community in accordance with the rules, both management procedures, requirements, processing time, official fees required for the validity period of the ID card.

\section{Factors Influencing the Implementation of the Role of the Government Bureaucracy in the Government Administration Process in Maros Regency}

implementation of its role and function as a government bureaucracy in realizing the government administration process is inseparable from the inhibiting and supporting factors. Because the existence of these factors will support the implementation of government bureaucratic arrangements in realizing the government administration process in Maros Regency.

Factors in the implementation of public services, especially regarding the service of making ID cards in Maros Regency, the author finds or identifies influencing factors, including the following:

\section{Supporting Factors}

1) The ability of the apparatus in serving the community

The ability of the bureaucratic apparatus that the author means here is the ability bureaucratic apparatus in serving the community, especially in making identity cards (KTP). In other words, that the bureaucratic apparatus must know about the Main Duties and Functions (Tupoksi), so that in the implementation of tasks to serve the community there will be no overlapping implementation which can avoid the flow of activities of a task not being smooth. Each bureaucratic apparatus is given the authority according to its duties and functions, so that it will give birth to an attitude of professionalism from the government apparatus.

According to one of the KTP service officers interviewed, he said:

"We officers of the ID card making service, when carrying out our duties feel a challenging burden of responsibility that must be resolved, not just carrying out orders that are only carried out because of an attitude of sheer loyalty". ${ }^{22}$

Based on this statement, public services, especially in the service of identity cards in Maros Regency in terms of the ability of the apparatus, can be categorized as effective. Although in principle the ability of the apparatus must be improved through education and training concerning public services in accordance with the demands of excellent and quality public services.

2) The Public service budget

implementation of government services in Maros Regency, it is realized that it definitely requires a financing budget in its implementation. Especially in the implementation of public

\footnotetext{
${ }^{22}$ The Indonesian Electronic Identity Card in The Office of Population's Civil Registration Maros Regency, Interview by Arifuddin.N (28 Januari 2020)
} 
services, they will always be faced with the availability of a budget for that, both from the community who want to get public services from the government as a public servant.

The source persons acknowledged that the implementation of public services is indeed influenced by the availability of funds, it can be seen from the statement of the resource persons who stated that:

"To serve the people, quite a lot of operational funds are needed, which can support the technical implementation of services. Because the replacement costs paid by the community are not sufficient to finance facilities and infrastructure as well as operational costs. The government has also prepared a budget for it." 23

From the results of the analysis, it was found that to support the technical operations of public services, especially regarding the KTP service in Maros Regency, the Maros Regency Government has prepared sufficient funds, so that the cost/budget does not depend on the contribution paid by the community.

This indicates that the public service budget prepared by the Maros Regency Government is a factor that strongly supports the success of public services in Maros Regency in supporting the government administration process.

\subsection{Inhibiting Factors}

\section{a. Service Procedures}

The service process that is convoluted or slow in public services

\footnotetext{
${ }^{23}$ Head of the financial sub-section of The Office of Populations Civil Registration Maros Regency, Interview by Arifuddin.N, (28 Januari 2020)
}

is something that is not desired by the community. The desire of the community to be served quickly and smoothly is something that the public service bureaucratic apparatus always strives for,

Based on the statement that has been disclosed in the discussion above about the procedural implementation of public services regarding the making of ID cards, which is stated in the findings that the service provider must go through the RT/RW hierarchy, The Head of the Village/Lurah, Sub-district then to the Population Service is a very long and convoluted procedure.

The procedure/mechanism for the ID card service can also be carried out directly at the Population Service but must be known by the Village Head/Lurah where the applicant is domiciled. Thus, there are two mechanisms that can be taken in public services, which then identifies that convoluted and slow services are still often found. So that the effectiveness and efficiency of services in Maros Regency still need serious attention by the Regional Government, because this then becomes one of the inhibiting factors.

b. Factors of Service Facilities and Infrastructure

Based on the results of the research, it turns out that the availability of facilities and infrastructure is not adequate for the benefit of public services, especially for 
making Identity Cards. This can be seen in the computer facilities, which only amount to 4 units to serve 14 sub-districts within the Maros Regency. The quality of the computer facilities and printing machines that are owned are often damaged so that it slows down the affairs of service to the community. A statement from a source said:

"Our computers are often damaged, thus making the input and printing of ID cards often having a delay". ${ }^{24}$

Therefore, the researcher concludes that facilities and infrastructure are one of the inhibiting factors that are quite influential, so that the process of providing Identity Card services still takes a long time to complete.

\section{CONCLUSION}

After going through the discussion, the results achieved in this study can be concluded as follows: The process of government administration in Maros Regency, can be seen from the administrative management process by looking at the level of ease of service procedures, speed of service, Low cost charged to the community, professionalism of the apparatus in providing services. Thus, the Maros Regency Government in realizing the government administration process has been running, although it is still not optimal. This is because there are still deviations that occur in terms of public services to the community,

\footnotetext{
${ }^{24}$ The Indonesian Electronic Identity Card in The Office of Population's Civil Registration Maros Regency, Interview by. Arifuddin.N (28 Januari 2020)
}

although this is still in the stage of improvement towards excellent service standards, but with the achievement of the Community Satisfaction Index in the first semester of 2020, the Service Unit obtained a total IKM score of 83.79 which shows a very good result. It shows that, the implementation of Law no. 25 of 2009 concerning Public Services and Law no. 30 of 2014 concerning Government Administration can run well. Influential Factors in the Implementation of Bureaucratic Arrangements, on the implementation of public services in Maros Regency in serving the community and the availability of sufficient budget to support the operational implementation of public services. Factors that affect community empowerment are the ability of the bureaucratic apparatus to oversee community empowerment in accordance with the applicable local regulations, the role of community institutions in the development process is not yet optimal, the community's understanding of the stages and processes of development is still low, the limitations of supporting facilities and infrastructure, improving services to the community is the level of education apparatus is still low, lack of budget allocations, and facilities and infrastructure are still lacking.

\section{Suggestions}

By paying attention to the results of research on bureaucratic arrangement in the process of government administration in Maros Regency, it should:

a. Continue to encourage the growth of professionalism for bureaucratic apparatus in the administration of government in Maros Regency. So that the government bureaucratic apparatus is able to implement government policies that lead to the realization 
of structuring government administration towards excellent service in Maros Regency

b. In supporting the implementation of the process of structuring government administration, facilities and infrastructure are needed that support all programs to be implemented. Provide understanding from all bureaucratic apparatus and the public about all applicable regulations in the Maros Regency Government, especially regulations related to the government administration process. By carrying out education and training for bureaucratic apparatus.

\section{ACKNOWLEDGMENTS}

The authors would like to thank the

1. Chairperson of STISIP Petta Baringeng Soppeng, as well as the Chairperson of the Government Science Study Program who provided recommendations to the authors to carry out research.

2. Regent / Deputy Regent of Maros Regency who has given permission to carry out research in his working area.

3. All Maros Regency Government Apparatus, starting from Assistant I of Maros Regency Government, Head of Subdistrict in Maros Regency, and ASN at the Population and Civil Registry Office of Maros Regency.

4. All parties who have contributed in carrying out the research until the completion of this article.

\section{BIBLIOGRAPHY}

\section{Books}

Dewata, Mukti Fajar Nur, and Yulianto Achmad. Dualisme Penelitian Hukum Normatif \& Empiris. Yogyakarta: Pustaka Pelajar, 2015.
Hummel, Ralph P. The Bureaucratic Experince. New York: St. Martin Press, 1982.

Moerdiono. Birokrasi Dan Administrasi Pembangunan: Beberapa Pemikiran Pemecahan. Jakarta: Pustaka Sinar Harapan, 1992.

Said, M. Mas'ud. Birokrasi Di Negara Birokratis. Malang: Universitas Muhammadiyah Malang Press, 2007.

Soekanto, Soerjono. Pengantar Penelitian Hukum. Jakarta: UI Press, 1983.

\section{Journal}

Haning, Mohammad Thahir. "Reformasi Birokrasi Di Indonesia: Tinjauan Dari Perspektif Administrasi Publik." JAKPP (Jurnal Analisis Kebijakan \& Pelayanan Publik) 4, no. 1 (2018): 31-32. https:// journal.unhas.ac.id/index.php/jakpp/ article/view/5902.

Nurmandi, Achmad. "Perilaku Birokrasi Publik Di Indonesia: Sebuah Kajian Teoritis." Sosiohumaniora: Journal of Social Sciences and Humanities 7, no. 2 (2005): 155. https://jurnal.unpad.ac.id/ sosiohumaniora/article/view/5546.

Rasul, Imran, and Daniel Rogger. "Management of Bureaucrats and Public Service Delivery: Evidence from the Nigerian Civil Service." The Economic Journal 128, no. 608 (February 1, 2018): 413-446. https://doi.org/10.1111/ ecoj.12418.

Yusriadi, Yusriadi, and Misnawati. "Reformasi Birokrasi Dalam Pelayanan Publik (Studi Pelayanan Terpadu Satu Pintu).” Jurnal Ilmiah Ilmu Administrasi Publik 7, no. 2 (2017): 102. https://ojs.unm.ac.id/iap/ article/view/4954.

Yusrialis. "Budaya Birokrasi Pemerintahan (Keprihatinan Dan Harapan)." Sosial 
Budaya 9, no. 1 (2012): 102.http://ejournal. uin-suska.ac.id/index.php/SosialBudaya/ article/view/372.

\section{Interview}

Administrative Section of the Population and Civil Registry Office of Maros Regency, Interview by, Arifuddin.N (20 Januari 2020).

Assistant I Governance law Administration of Maros Regency, Interview by Arifuddin N, (14 Januari 2020)

Department of Population and Civil Registration, Maros Regency, Interview, by Arifuddin.N (16 Januari 2020)

Head of the financial sub-section of The Office of Populations Civil Registration Maros Regency, Interview by Arifuddin.N, (28 Januari 2020)
The Indonesian Electronic Identity Card in The Office of Population's Civil Registration Maros Regency, Interview by Arifuddin.N (28 Januari 2020

\section{Law and Regulation}

Law Number 22 of 1999 concerning Regional Administrations

Law Number 32 of 2004 concerning Regional Administrations

Law Number 25 of 2009 concerning Public Service Law

Law Number 23 of 2014 concerning Regional Administrations

Law Number 30 of 2014 concerning Government Administration 